\title{
THE INVESTIGATION OF THE INFLUENCE OF PSYCHOLOGICAL CONTRACT TYPES ON ORGANIZATIONAL CITIZENSHIP BEHAVIOUR
}

\author{
UDC 349.2:331.106]:005.32
}

\section{Ivana Simić, Biljana Đorđević, Sandra Milanović*}

\author{
University of Niš, Faculty of Economics, Serbia
}

\begin{abstract}
Organizational citizenship behaviour represents the behaviour of the employees that goes beyond their duties. This type of behaviour from the perspective of employer is very desirable since it produces many positive consequences regarding individual and the overall organizational performances. However, readiness of the employees to exert this type of behaviour is influenced by many factors. One of the most important is fulfilment of employees' psychological contract. Since that there are two basic forms of contracts, relational and transactional, the aim of this paper is to investigate the relationship between these types of psychological contract and organizational citizenship behaviour. For the purpose of testing proposed hypothesis, $t$ test, Pearson correlation and multiple linear regression analysis were applied. The results showed that there is a positive relation and positive impact of relational psychological contract on the organizational citizenship behaviour, which was not the case when it was about the transactional contract.
\end{abstract}

Key words: relational psychological contract, transactional psychological contract, organizational citizenship behaviour, employees.

JEL Classification: J28, J29

\section{INTRODUCTION}

The history of studying the psychological contract begins in 1960s (Argyris, 1960; Levinson et al., 1962; Schein, 1965), but the interest for this concept has grown significantly in the last few decades. The reason for that is that psychological contract

Received June 07, 2019 / Accepted September 18, 2019

Corresponding author: Sandra Milanović

* PhD Student, Junior Researcher

University of Niš, Faculty of Economics, Trg Kralja Aleksandra Ujedinitelja 11, 18000 Niš, Serbia

E-mail: sandramilanovic89@yahoo.com 
appears to be very useful tool to resolve many important human resource related issues (Chahar, 2019). It appears that psychological contract is very useful concept for explanation of the issues of motivation (Pines, 2002; Parzefall \& Hakanen, 2010), satisfaction of employees (Knights \& Kennedy, 2005; Zhao et al., 2007; Suazo, 2009), turnover intentions (Hess \& Jepsen, 2009), absenteeism (Griffeth et al., 2000), commitment, etc. (Robinson \& Morrison, 1995; Anderson \& Schalk, 1998; Cassar \& Briner, 2011). Kishokumar (2018) also states that psychological contract is essential to understand the nature of employeeemployer relationship and to maintain positive relationship between them.

In addition to the fact that psychological contract is a useful concept for the explanation of previously mentioned employees' work related attitudes and behaviour, it is also a very useful concept to explain why some employees engage in the activities that go beyond their job description. In other words, this concept is very useful for the explanation of the organizational citizenship behaviour of employees. In this regard, in many studies positive relationship was found between the fulfilment of employees' psychological contract and organizational citizenship behaviour (Marks, 2001; Karagonlar et al., 2016; Guest, 2016). On the other hand, it was found that violation of the psychological contact has negative impact on the readiness of employees to exert organizational citizenship behaviour (Cassar \& Briner, 2009).

Although that there are plenty of studies of relationship between psychological contract (PC) and organizational citizenship behaviour (OCB) in the literature so far, it appears that in the most of them PC was seen as one-dimensional construct. However, in order to get better insight into the relationship between PC and OCB of employees, it is very useful to investigate the influence of different types of PC on OCB of employees. Namely, it is a very well-known fact that the basic types of PC are relational and transactional (MacNeil, 1980; Rousseau, 1990; Robinson et al., 1994). Therefore, it would be very useful to investigate the relation between relational PC and OCB of employees as well as the relationship between transactional PC and OCB of employees.

In order to find out the answers on what kind of relationship is between mentioned types of PC and OCB of employees', an empirical study was conducted on the sample of academic professors at state universities in Serbia. This country is interesting for the research in this area since due to socialism it has had a long tradition of paternalistic relation of organisations toward employees. Therefore, it is interesting firstly to find out whether employees dominantly form relational or transactional PC and, secondly, to investigate what is the relationship between different types of $\mathrm{PC}$ and $\mathrm{OCB}$ of employees.

The paper is structured as follows. In the first part of the paper the literature review on the concepts of organizational citizenship behaviour and psychological contract is given. In the second part, the methodology of the research, the research results and their discussion are presented. The final part of the paper refers to the practical implication of the paper and concluding remarks.

\section{LITERATURE REVIEW AND HYPOTHESIS DEVELOPMENT}

\subsection{Organizational citizenship behaviour}

The concept of OCB has been established in the literature in the seventies of the twentieth century, but demonstrating of this type of behaviour in working place is much older. In some simplified form, this type of behaviour could be identified with the appearance of the first organizations. 
In the literature, the form of OCB was identified for the first time by Daniel Katz in 1964, although he did not use that term. Such form of behaviour was denoted by Katz (1964) as ,an extra-role behaviour”. Katz (1964) explained it as a form of behaviour of organizational members which is not defined by their formal roles and tasks within the organization. More precisely, the mentioned author saw this type of behaviour as behaviour that implies willingness and readiness of organizational members to make additional efforts and to do more in relation to what is formally expected of them.

The creators of the very term Organizational Citizenship Behaviour are Denis W. Organ and his colleagues. It appeared in their paper "Organizational Citizenship Behaviour: Its nature and antecedents" published in 1983 (Smith et al., 1983). Since the concept of OCB has aroused interest of many authors, many definitions of this term appeared in the literature lately. First of all, Organ, as a creator of this term, defined OCB as individual behaviour that is discretionary, not directly or explicitly recognized by the formal reward system, and that in aggregate promotes effective functioning of the organization (Organ, 1988 , p. 4). OCB is also defined as any positive organizationally relevant behaviour of organizational members including their in-role behaviour, organizationally pertinent extrarole behaviour, and political behaviour (Cummings et al. 1994, p. 766). It was also seen as a set of desirable organizational behaviour that exhibits multidimensional relationships with positive organizational consequences (Waltz \& Niehoff, 2000).

In order to determine OCB more precisely, Denis Organ (1988) pointed five key dimensions of it. They are: altruism, conscientiousness, sportsmanship, courtesy and civic virtue (Organ, 1988). Their basic characteristics are explained in the following text.

Altruism reflects the willingness of organization's members to help their colleagues, or their readiness to spend their own time and energy on others. It is considered that this dimension of OCB has great potential to contribute to enhancing the performances of the employee to whom the altruistic behaviour is channelled.

Conscientiousness, according to Organ, reflects the willingness of members of the organization to use their own time and other available resources efficiently and rationally, as well as to provide an extra contribution to the organization by their complementary efforts.

Sportsmanship refers to the readiness of organizational members to spend their time and energy for constructive purposes within the organization, and not to complain about some trivial problems or uncomfortable working conditions they currently may face with, to sacrifice personal interests for the organizational ones, etc. The same opinion regarding this dimension of OCB is also shared by Podsakoff and his colleagues (2000), and many other authors.

Courtesy behaviour of members of the organization involves the efforts to share the available information with their colleagues, to remind them of some of their obligations, and so on. Such form of behaviour enables co-workers to use their resources and energy more efficiently, and to reduce the level of stress, anger, frustration and conflict. In some specific way, this type of behaviour maintains social order and raises the level of harmony within the organization (Organ, 1988; Wang et al, 2013).

Civic virtue refers to willingness or unwillingness of an organizational member to participate actively in the political life of the organization. This type of behaviour is based on the assumption that most of employees usually have the right to take part in some organizational meetings in which their participation is not required, to analyse some organizational issues on personal time, to express their own opinion and so on (Wang et al., 2013). 
The mentioned list of OCB dimensions has been corrected by some theorists, whether they have narrowed or expanded it. Thus, for example, P. M. Podsakoff and his colleagues (2000) proposed seven dimensions of the OCB. They are: helping behaviour, sportsmanship, organizational loyalty, organizational compliance, individual initiative, civic virtue, self development (Podsakoff et al., 2000).

The degree to which employees will express the OCB form of behaviour is determined by a number of factors. Some studies have shown that among the most influential are: job satisfaction, organizational commitment, perceptions of organizational justice, leader support, trust in management, psychological contract etc. (Swaen \& Maignan, 2003; Chahar, 2019; Kishokumar, 2018). Considering that the aim of this paper is to explain the influence of the PC (more precisely, some of its types) on OCB, the essence of this concept is presented in the following text.

\subsection{Psychological contract}

The concept of PC originated in 1960 (Argyris, 1960), but significant contribution to its development was given by many authors lately. However, probably the most significant contribution to the development of the theory of PC in recent period was given by Denise Rousseau. She was the first one who defined PC from an individual's perspective, stating that it represents "an individual's belief regarding the terms and conditions of a reciprocal exchange agreement between that focal person and another party (usually between an employer and an employee)" (Rousseau, 1989, p.123). Employees usually expect to be treated fairly as human beings, to be provided with the work that uses their abilities, to be rewarded equitably in accordance with their contribution, to be able to display competence, to have opportunity for further growth and to know what is required from them.

The PC has several basic characteristics that distinguish it from the legal employment contract. The first basic characteristic is that $\mathrm{PC}$ is not documented and has very intangible nature (Chahar, 2019). Other important characteristics of PC are that it has perceptual nature, it is based on promises, the elements which the PC consists of have reciprocal nature, it has a dynamic nature, expectations which PC consists of are conditioned by previous experience, etc. (Rousseau, 1995; Anderson, 1998; Davidson, 2002).

Speaking of the types of PC, there are several classifications that could be found in the literature. Firstly, PC could be seen as the "old" one and the "new" one. The basic characteristic of the "old" PC is that employees who form this type of PC believe that if they work hard, adequately fulfil their obligations to the employer and contribute to the achievement of company's goals, can count on job security (Dunahee \& Wangler, 1974; Rousseau 1989; Sims, 1994; Makin et al. 1996; Singh, 1998). However, after 80s of the $20^{\text {th }}$ century, when many companies went through mergers, acquisitions and downsizing processes (and consequently many employees were laid off), employees started to form the "new" form of PC (Milanović et al., 2018). Its fundamental characteristic is that employees cannot count on job security any more. They realized that the best that they can get from the employers are fair salary and opportunities for personal growth (Sims, 1994; Robinson et al., 1994; Kissler, 1994; Sparrow, 1996; Hiltrop, 1996; Schalk \& Roe 2007).

Beside the mentioned classification of PC, the classification of the elements of which PC dominantly consists of is also very well-known in the literature. Accordingly, there are two additional types of PC: transactional and relational (MacNeil, 1980; Rousseau, 1990; Robinson et al., 1994). Relational contact reflects employees' affective involvement and beliefs in organizations that they will provide guarantees for employees' career 
development, respect, support, etc. In turn, the employees offer loyalty and commitment to the organization's needs and interests. Based on this, when it is about the OCB, which also assumes positive attitudes regarding organization, it is reasonable to expect that the employees who develop relational PC demonstrate OCB as well. Therefore, the hypotheses that are going to be tested in our research are as follows:

H1: There is a positive relationship between relational $P C$ and $O C B$ of employees.

H2: There is the positive impact of PC on OCB of employees.

In contrast to relational PC, transactional contract is based on the material benefits. The employees who form this type of PC do not become the organizational members really but they are only concerned about the short-term material rewards and personal benefits (Kiskohumar, 2019). Closed-ended time frame, exchange of economic resources, unambiguous performance standards and limited mutual investment between employer and employees are also the basic characteristics of transactional contract (Robinson \& Morrison, 1995). Since the employee who forms transactional PC has no obligation to remain within the organization and perform only a limited or fixed set of duties, it is reasonable to expect that they do not demonstrate OCB. Therefore, additional hypothesis that are going to be tested in the research are as follows:

H3: There is negative relationship between transactional PC and OCB of employees.

H4: There is the negative impact of transactional PC on OCB of employees.

Since Serbia had a long tradition of socialism, which assumes paternalistic relationship toward employees, it is reasonable to expect that in most cases employees (in our research academic professors) form relational PC. Therefore, our next hypothesis is:

H5: Academic professors rank relational PC higher than transactional PC.

\section{METHODOLOGY OF RESEARCH}

Context of the research. The research has been conducted on the sample of academic professors at state universities and higher schools on the territory of the Republic of Serbia. In Serbia there are eight state universities. The participants of the study were the professors of two universities (University of Novi Sad, which is at the north of Serbia, and University of Niš, which is at the south of Serbia) and one higher school.

Research variables and instruments. Regarding the PC, we used the questionnaire Psychological Contract Scale developed by Millward and Hopkins (1998) and later adapted by Raja et al. (2004). Raja et al. (2004) measured two components of PC, transactional and relational, with 9 items per each category. Furthermore, a sixteen-item measure (based on the work of Podsakoff et al. (1990), Podsakoff and MacKenzie (1994) and adapted by Shahzad (2011) was used to access OCB. Participants were asked to access all the items in the questionnaire on five-point Likert scale, ranging from 1 - strongly disagree, to 5 strongly agree. In both questionnaires, reversed coding was applied with the aim of getting the same direction of items. Reliability test by comparing the value of the coefficient Cronbach Alpha with the criteria of a minimum value of 0.6 , defined by Griethuijsen et al. (2014), showed the value of 0.85 for relational $\mathrm{PC}$ and 0.73 for OCB, all above the threshold. After excluding two items for transactional PC, acceptable level of Cronbach Alpha coefficient of 0.65 was achieved. 
Data collection techniques and instruments. The authors distributed 120 questionnaires in paper form during the winter semester of school year 2018/2019. Four faculties (from two universities) and one higher school took part in the research. The response rate was $80.83 \%$ with no missing data and, thus, all returned questionnaires were used in the research.

The sample characteristics. The demographic characteristics of the respondents are presented in the Table 1.

Table 1 Respondent Characteristics

\begin{tabular}{ccc}
\hline \multicolumn{1}{c}{ Variable } & Frequency & Percent \\
\hline Gender & 97 & 100 \\
Male & 40 & 41.2 \\
Female & 57 & 58.8 \\
Age & 97 & 100 \\
$<30$ & 15 & 15.5 \\
$31-40$ & 36 & 37.1 \\
$41-50$ & 26 & 26.8 \\
$51-60$ & 13 & 13.4 \\
$>61$ & 7 & 7.2 \\
Work experience & 97 & 100 \\
$<5$ years & 15 & 15.5 \\
6-15 years & 37 & 38.1 \\
16-25 years & 29 & 29.9 \\
$>$ 26 years & 16 & 16.5 \\
Position & 97 & 100 \\
Full Professor & 19 & 19.6 \\
Associate Professor & 22 & 22.7 \\
Assistant Professor & 17 & 17.5 \\
Assistant & 36 & 37.1 \\
Teaching Associate & 3 & 3.1 \\
\hline
\end{tabular}

Source: Authors' calculations

Analyses and procedures. The IBM program SPSS, version 23 was used in order to analyse obtained data. For the purpose of testing proposed hypothesis, t-test, Pearson correlation and multiple linear regression analysis were applied. According to Cohen (1992), Pearson correlation coefficient values of \pm .10 represent a small effect, \pm .30 is a medium effect and \pm .50 is a large effect.

\section{THE RESULTS AND DISCUSSION}

This section provides the findings and discussion on relationship and influence of two types of PC (relational and transactional) on OCB of academic professors participated in the research.

Table 2 Descriptive statistics of the researched variables

\begin{tabular}{lcccccc}
\hline Variable & $\mathrm{N}$ & Minimum & Maximum & Mean & SD & SE \\
\hline Transactional PC & 97 & 1.00 & 3.86 & 1.93 & .53 & .054 \\
Relational PC & 97 & 1.89 & 4.44 & 3.34 & .53 & .053 \\
OCB & 97 & 3.06 & 5.00 & 4.17 & .39 & .393 \\
\hline \multicolumn{7}{c}{ Source: Authors' calculations }
\end{tabular}


Table 2 shows that the mean value for transactional PC was $1.93(\mathrm{SD}=0.53)$ indicating relatively low level of reciprocal transactional obligations between an employee and his or her organization. On the other hand, the mean value of relational PC is $3.34(\mathrm{SD}=0.53)$ showing relatively high level of relational PC. OCB has mean value of 4.17 (SD = 0.39) indicating relatively high level of OCB among academic professors. All standard deviations have values on acceptable level.

In order to test the first and the third hypothesis, the correlation between transactional $\mathrm{PC}$, relational PC and OCB were calculated.

Table 3 Correlations between researched variables and reliabilities ${ }^{\text {a }}$

\begin{tabular}{llll}
\hline Variable & 1 & 2 & 3 \\
\hline 1. Transactional PC & $(.65)$ & & \\
2. Relational PC & $-.267^{* *}$ & $(.85)$ \\
3. OCB & $-.510^{* *}$ & $.497^{* *}$ & $(.73)$ \\
\hline \multicolumn{2}{c}{${ }^{\mathrm{a}} \mathrm{n}=97$; alpha reliabilities are given in parentheses } \\
**. Correlation is significant at the 0.01 level (2-tailed). \\
Source: Authors' calculations
\end{tabular}

Table 3 shows that the Pearson correlation coefficient is $r=-0.510(p<0.01$, large practical effect) indicating that there is a negative correlation between transactional PC and OCB of academic professors. The same analysis revealed positive $(r=0.497)$ and statistically significant correlation $(\mathrm{p}<0.01$, medium practical effect) between relational $\mathrm{PC}$ and OCB of professors participated in the research.

Previous analysis indicates that the hypothesis $\mathrm{H} 1$, defined as that there is a positive relationship between relational PC and OCB of employees is confirmed. Also, the hypothesis $\mathrm{H} 3$, which proposed that there is a negative relationship between transactional PC and OCB of employees, is confirmed. More precisely, the previous analysis showed that when the level of relational PC increases, the level of OCB increases as well and when the level of transactional PC increases, the level of OCB decreases.

In order to test the second and the forth hypothesis, multiple linear regression analysis was applied to investigate if there is the effect of relational and transactional PC on OCB (Table 4).

Multiple linear regression analysis (Table 4) displays $\mathrm{R}$ value of 0.633 . $\mathrm{R}$ Square $=$ 0.401 indicating that components of PC are influencing $40.1 \%$ of change in OCB of academic professors. F statistics is 31.452, statistically significant at the level of 0.000 (p < 0.05 ) indicating that there is a model fit between independent variables and dependent variable. Regression coefficients for transactional PC $(B=-0.296 ; p<0.05)$ and for relational $\mathrm{PC}(\mathrm{B}=0.286 ; \mathrm{p}<0.05)$ imply that these variables significantly contribute to the OCB of respondents. Hence, the regression equation for OCB can be written as follows:

$$
\text { OCB }=3.783-0.296(\text { Transactional PC })+0.286(\text { Relational PC) }
$$


Table 4 Regression analysis of studied variables

Model Summary

\begin{tabular}{rccccccccc}
\hline & & & & \multirow{6}{c}{ Change Statistics } & \\
Model & $\mathrm{R}$ & R Square & $\begin{array}{c}\text { Adjusted } \\
\text { R Square }\end{array}$ & $\begin{array}{c}\text { Std. Error } \\
\text { of the } \\
\text { Estimate }\end{array}$ & $\begin{array}{c}\text { Square } \\
\text { Change }\end{array}$ & $\begin{array}{c}\mathrm{F} \\
\text { Change }\end{array}$ & df1 & df2 & $\begin{array}{c}\text { Sig. F } \\
\text { Change }\end{array}$ \\
\hline 1 & $.633^{\mathrm{a}}$ & .401 & .388 & .30325 & .401 & 31.452 & 2 & 94 & .000 \\
\hline
\end{tabular}

a. Predictors: (Constant), Transactional PC, Relational PC

ANOVA $^{\text {a }}$

\begin{tabular}{llrrrrr}
\hline Model & & Sum of Squares & df & Mean Square & F & Sig. \\
\hline 1 & Regression & 5.785 & 2 & 2.892 & 31.452 & $.000^{\mathrm{b}}$ \\
& Residual & 8.645 & 94 & .092 & & \\
& Total & 14.429 & 96 & & & \\
\hline \multicolumn{5}{c}{ a. Dependent Variable: OCB } \\
& b. Predictors: (Constant), Transactional PC, Relational PC
\end{tabular}

Coefficients ${ }^{\text {a }}$

\begin{tabular}{|c|c|c|c|c|c|c|c|c|c|}
\hline \multirow{2}{*}{ Model } & \multicolumn{3}{|c|}{$\begin{array}{cc}\text { Unstandardized } & \text { Standardized } \\
\text { Coefficients } & \text { Coefficients } \\
\end{array}$} & \multirow{2}{*}{$\mathrm{t}$} & \multirow{2}{*}{ Sig. } & \multicolumn{2}{|c|}{$\begin{array}{c}95.0 \% \text { Confidence } \\
\text { Interval for B } \\
\end{array}$} & \multicolumn{2}{|c|}{$\begin{array}{c}\text { Collinearity } \\
\text { Statistics }\end{array}$} \\
\hline & B & $\begin{array}{l}\text { Std. } \\
\text { Error }\end{array}$ & Beta & & & $\begin{array}{l}\text { Lower } \\
\text { Bound }\end{array}$ & $\begin{array}{l}\text { Upper } \\
\text { Bound }\end{array}$ & Tolerance & VIF \\
\hline 1 (Constant) & 3.783 & .263 & & 14.405 & .000 & 3.262 & 4.305 & & \\
\hline Transactional PC & -.296 & .060 & -.406 & -4.906 & .000 & -.416 & -.176 & .929 & 1.077 \\
\hline Relational PC & .286 & .061 & .389 & 4.694 & .000 & .165 & .408 & .929 & 1.077 \\
\hline
\end{tabular}

a. Dependent Variable: Organizational citizenship behaviour

Source: Authors' calculations

Due to significant correlation between independent variables (Table 3), Tolerance and VIF tests were applied. Their values are on the acceptable level, VIF $<10$ and Tolerance $>$ 0.1 , thus there is not a problem of multicollinearity among these variables (Field, 2009).

It can be concluded that hypotheses $\mathrm{H} 2$ stated as that there is the positive impact of relational $\mathrm{PC}$ on $\mathrm{OCB}$, and $\mathrm{H} 4$ that there is the negative impact of transactional $\mathrm{PC}$ on OCB are also confirmed.

The results of our research are moderately in line with the results of other authors who investigated the relationship between different types of PC and OCB. Our research is similar to Mai et al. (2016). They found significant correlations between transactional PC $(\mathrm{r}=-0.37, \mathrm{p}<0.01)$ and relational PC $(\mathrm{r}=0.50, \mathrm{p}<0.01)$ with OCB. Kishokumar $(2018)$ identified that relational PC and OCB were positively correlated $(\mathrm{r}=0.825, \mathrm{p}<0.01)$. Contrary to our findings, Kishokumar (2018) revelled that transactional PC is positively related with OCB $(r=0.814, p<0.01)$. Similarly to this research, relationship between transactional PC and OCB was positive $(\mathrm{r}=0.158, \mathrm{p}<0.05)$ and also between relational PC and OCB $(r=0.198, p<0.001)$ in research of Byoung et al. (2014). Concerning the effects of transactional PC and relational PC, Byoung et al. (2014) proved that the positive relationship between organizational identification and OCB will be stronger when the transactional contract is low and when the relational contract is high. More extended research of Hui et al. (2004) has shown that transactional and relational PC were positively 
related with all five components of OCB: altruism, conscientiousness, civic virtue, courtesy, sportsmanship. Furthermore, the transactional PC had a direct effect on OCB, but relational PC did not. It predicted instrumentality, which in turn predicted all OCB components. Findings of Lub et al. (2011) indicate that both transactional PC $(r=0.235, \mathrm{p}<0.05)$ and relational PC $(r=0.363, p<0.01)$ are positively related with OCB. Regression analysis showed that $27 \%$ of variance in OCB was due to change in transactional and relational PC, but only regression coefficient for relational $\mathrm{PC}$ was statistically significant and positive $(\mathrm{B}=0.37, \mathrm{p}<0.01)$

In order to test the hypothesis H5 we conducted t-test to compare values of relational and transactional PC with defined test value of 3 . The results have shown that academic professors rank relational $\mathrm{PC}(\mathrm{t}=6.474, \mathrm{df}=96 \mathrm{p}=0.000)$ higher than transactional $\mathrm{PC}$ $(\mathrm{t}=-19.719, \mathrm{df}=96, \mathrm{p}=0.000)$ indicating that hypothesis $\mathrm{H} 5$ is confirmed.

These findings indicate that academic professors vastly rate relational $\mathrm{PC}$, which is positively related with their OCB. Since the transactional PC is negatively related with OCB, variations in OCB of academic professors are explained by positive effect of relational and negative effect of transactional PC.

\section{CONCLUSION}

Organizational citizenship behaviour is a form of employees' behaviour which is very beneficial for the employers. It could result in increasing of the individual performances and in enhancement of the overall organizational performances. Therefore, this form of behaviour is very desirable in working place. However, it is influenced by the set of factors among which the fulfilment of the psychological contract is one of the most important ones.

In this paper, the relationship between PC types and OCB was analysed. After presenting the theoretical background of these concepts, the results of the empirical study were presented and analysed. The study has been conducted on the sample of academic professors at state universities in Serbia. Since they work in relatively stable environment and certain percentage of professors had lived partly in socialism, the authors of the paper assumed that the dominant form of psychological contract that they develop is relational. The authors also assumed that there is positive relationship and positive impact of relational PC on OCB of respondents. On the other hand, when it is about the transactional contract, the assumption was that there is negative relationship and negative impact on organizational citizenship behaviour. The results of the study showed that all proposed hypothesis are confirmed.

However, there are some limitations of this study. Firstly, the research sample was dominated by academic professors. Research on a more diverse sample is required to gain more reliable results. Secondly, because of the small sample, generalizations of the relationship between PC type and OCB of employees in Serbia could not be made. But regardless of these limitations, the information gained from this research could be beneficial, first of all, for those universities participating in the study in order to improve some human resource management practices and communicational channels. As final consequences of that will be the fulfilment of PC of employees at higher level which will bring many positive consequences in working environment. 


\section{REFERENCES}

Anderson, N. \& Schalk, R. (1998). The psychological contract in retrospect and prospect. Journal of Organizational Behaviour, 19, 637 - 647. doi: 10.1002/(SICI)1099-1379(1998)19:1+<637:: AID-JOB986>3.0.CO;2-H

Argyris, C. (1960). Understanding Organizational Behaviour. Homewood, IU.: Dorsey Press.

Byoung, K.C., Hyoung, K.M., Wook, K. \& Kyoung, M.K. (2014). A cross-sectional study of the relationships between organizational justices and OCB: Roles of organizational identification and psychological contracts. Leadership \& Organization Development Journal, 35 (6), 530-554. doi: 10.1108/LODJ-08-2012-0103

Cassar, V. \& Briner, R. (2011). The Relationship between Psychological Contract Breach and Organizational Commitment: Exchange Imbalance as a Moderator of the Mediating Role of Violation. Journal of Vocational Behaviour, 78, 283-289. doi: 10.1016/j.jvb.2010.09.007

Cassar, V. \& Briner, R. (2009). Contextualizing the Features of the Psychological Contract: The Case of Malta. Journal of Management Psychology, 24 (7), 677-694. doi: 10.1108/02683940910989048

Chahar, B. (2019). Psychological Contract and Organizational Citizenship Behaviour: Exploring the Interrelatedness through cross Validation. Academy of Strategic Management Journal, 18 (1), 1-15.

Cohen, J. (1992). Quantitative methods in psychology: A power primer. Psychological Bulletin, 112 (1), $153-$ 159. doi: $10.1037 / 0033-2909.112 .1 .155$

Cummings, L.L., Dyne L.V., Graham, J. \& Dienesch, R.M. (1994). Organizational Citizenship Behaviour: Construct Redefinition, Measurement, and Validation. Academy of Management Journal, 37 (4), 765-802. doi: $10.5465 / 256600$

Davidson, P. (2001). The Changing Nature of the Psychological Contract in the IT Industry: 1997-2001 (Research Papers in Human Resource Management), Kingston University Business School.

Dunahee, M.H. \& Wangler, L.A. (1974). The Psychological Contract: A Conceptual Structure for Management/Employee Relation. Personnel Journal, 53 (7), 518-526.

Field, A. (2009). Discovering statistics using SPSS ( $3^{\text {rd }}$ ed.). London: SAGE Publications Ltd.

Griethuijsen, R. A. L. F., Eijck, M. W., Haste, H., Brok, P. J., Skinner, N. C., Mansour, N., et al. (2014). Global patterns in students' views of science and interest in science. Research in Science Education, 45 (4), $581-$ 603. doi: 10.1007/s11165-014-9438-6

Griffeth, R.W., Hom, P.W. \& Gaertner, S. (2000). A meta-analysis of antecedents and correlates of employee turnover: Update, moderator tests, and research implications for the next millennium. Journal of Management, 26 (3), 463-488. doi: 10.1177/014920630002600305

Guest, D.E. (2016). Trust and the role of the psychological contract in contemporary employment relations. Building Trust and Constructive Conflict Management in Organizations (pp. 137-149): Springer. doi: 10.1007/978-3-319-31475-4_8

Hess, N. \& Jepsen, D.M. (2009). Career stage and generational differences in psychological contracts. Career Development International, 14, 261-283. doi: 10.1108/13620430910966433

Hiltrop, J.M. (1996). Managing the changing psychological contract. Employee Relations, 18 (1), 36-50. doi: $10.1108 / 01425459610110227$

Hui, C., Lee, C. \& Rousseau, D.M. (2004). Psychological Contract and Organizational Citizenship Behaviour in China: Investigating Generalizability and Instrumentality. Journal of Applied Psychology, 89 (2), 311-321. doi: $10.1037 / 0021-9010.89 .2 .311$

Karagonlar, G., Eisenberger, R. \& Aselage, J. (2016). Reciprocation wary employees discount psychological contract fulfillment. Journal of Organizational Behaviour, 37 (1), 23-40. doi: 10.1002/job.2016

Katz, D. (1964). The motivational basis of organizational behaviour. Behavioural Science, 9 (2), 131-146. doi: 10.1002/bs.3830090206

Kishokumar, R. (2018). The Impact of Psychological Contract on Organizational Citizenship Behaviour: An Investigation on Banking Sector in Eastern Province, Sri Lanka. Asian Journal of Economics, Business and Accounting, 6 (1), 1-13. doi: 10.9734/AJEBA/2018/38956

Kissler, G.D. (1994). The new employment contract. Human Resource Management, 33, 335-352. doi: 10.1002/hrm.3930330304

Knights, J.A. \& Kennedy, B.J. (2005). Psychological contract violation: Impact on job satisfaction and organizational commitment among Australian senior public servants. Applied H.R.M. Research, 10 (2), 57-72.

Levinson, H., Price, R.C., Munden, J.K., Mandl J.H. \& Solley, M.C. (1962). Men, management and mental health, Harvard University Press. doi: 10.1002/hrm.3930020108

Lub, X.D., Blomme, R.J. \& Bal, M.P. (2011). Psychological Contract and Organizational Citizenship Behaviour: A New Deal for New Generations? in Joseph S. Chen (Ed.) Advances in Hospitality and Leisure (pp. 109-130). Emerald Group Publishing Limited. doi: 10.1108/S1745-3542(2011)0000007010

MacNeil, I.R. (1980). The new social contract: An inquiry into modern contractual relations, New Haven: Yale University Press. doi: 10.1086/292419 
Mai, K.M., Ellis, A.P.J., Christian, J.S. \& Porter, C.O.L.H. (2016). Examining the effects of turnover intentions on organizational citizenship behaviours and deviance behaviours: A psychological contract approach. Journal of Applied Psychology, 101 (8), 1067-1081. doi: 10.1037/ap10000115

Makin, P.J., Cooper, C.L. \& Cox, C.J. (1996). Organizations and the psychological contract: managing people at work. Leicester: The British Psychological Society.

Marks, A. (2001). Developing a multiple foci conceptualization of the psychological contract. Employee Relations, 23 (5), 454-469. doi: 10.1108/EUM0000000005897

Milanović, S., Đokić, M. \& Đorđević, B. (2018). The influence of psychological contract breach on job satisfaction. Facta Universitatis, Series: Economics and Organization, 15 (3), 203-215. doi: 10.22190/FUEO1803203M

Millward, L.J. \& Hopkins, L.J. (1998). Psychological Contracts, Organizational and Job Commitment. Journal of Applied Social Psychology, 28, 1530-1556. doi: 10.1111/j.1559-1816.1998.tb01689.x

Organ, D. W. (1988). Issues in organization and management series. Organizational citizenship behaviour: The good soldier syndrome. Lexington, MA, England: Lexington Books/D. C. Heath and Com.

Parzefall, M.R. \& Hakanen, J. (2010). Psychological contract and its motivational and health-enhancing properties. Journal of Managerial Psychology, 25 (1), 4-21. doi: 10.1108/02683941011013849

Pines, A.M. (2002). The Changing Psychological Contract At Work And Employee Burnout. Journal of Health and Human Services Administration, 25, 11-32

Podsakoff, P.M., MacKenzie, S.B., Moorman, R. \& Fetter, R. (1990). Transformational leader behaviours and their effects on followers' trust in leader, satisfaction, and organizational citizenship behaviours. The Leadership Quarterly, 1 (2), 107-142. doi: 10.1016/1048-9843(90)90009-7

Podsakoff, P. M. \& MacKenzie, S. B. (1994). Organizational citizenship behaviour and sales unit effectiveness. Journal of Marketing Research, 31, 351-363.

Podsakoff, P.M., MacKenzie, S.B., Paine, B.P. \& Bachrach, D.G. (2000). Organizational citizenship behaviour: A critical review of the theoretical and empirical literature and suggestions for future research. Journal of Management, 26 (3), 513-563. doi: 10.1177/014920630002600307

Raja, U., Johns, G. \& Ntalianis, F. (2004). The impact of personality on psychological contracts. The Academy of Management Journal, 47, 350-367. doi: 10.2307/20159586.

Robinson, S.L., Kraatz, M. \& Rousseau, D.M. (1994). Changing obligations and the psychological contract: A longitudinal study. Academy of Management Journal, 37 (1), 137-152. doi: 10.2307/256773

Robinson, S.L. \& Morrison, W.E. (1995). Psychological contracts and OCB: The effect of unfulfilled obligations on civic virtue behaviour. Journal of Organizational Behaviour, 16 (3), 289-298. doi: 10.1002/job.4030160309

Rousseau, D.M. (1989). Psychological and implied contracts in organizations. Employer Responsibilities and Rights Journal, 2 (2), 121-139. doi: 10.1007/BF01384942

Rousseau, D.M. (1990). New hire perspectives of their own and their employer's obligations: A study of psychological contracts. Journal of Organizational Behaviour, 11 (5), 389-400. doi: 10.1002/job.4030110506

Rousseau, D.M. (1995). Psychological contracts in organizations: understanding written and unwritten agreements. London: Sage Publications.

Schalk, R. \& Roe, R. (2007). Towards a Dynamic Model of the Psychological Contract. Journal for the Theory of Social Behaviour, 37 (2), 167-182. doi: 10.1111/j.1468-5914.2007.00330.x

Schein, E.H. (1965). Organizational psychology. Englewood Cliffs, NJ: Prentice-Hall.

Schein, E.H. (1978). Career Dynamics: Matching Individual and Organizational Needs. Addison-Wesley.

Shahzad, K. (2011), Development of a Model of Organizational Citizenship Behaviour (OCB): A Comparative Study of University Teachers from a Developing and a Developed Country. Ph.D. Thesis. Islamabad: Mohammad Ali Jinnah University.

Sims, R.R. (1994). Human resource management's role in clarifying the new psychological contract. Human Resource Management, 33 (3), 373-382. doi: 10.1002/hrm.3930330306

Singh, R. (1998). Redefining psychological contracts with the U.S. workforce: A critical task for strategic human resource management planners in the 1990s. Human Resource Management, 37 (1), 61-69. doi: 10.1002/(SICI)1099-050X(199821)37:1<61::AID-HRM6>3.0.CO; 2-T

Smit, C.A., Organ, D.W. \& Near, J.P. (1983). Organizational citizenship behaviour: Its nature and antecedents. Journal of Applied Psychology, 68 (4), 653-663. doi: 10.1037/0021-9010.68.4.653

Sparrow, P.R. (1996). Transitions in the psychological contract: Some evidence from the banking sector. Human Resource Management Journal, 6 (4), 75-92. doi: 10.1111/j.1748-8583.1996.tb00419.x

Suazo, M. (2009). The mediating role of psychological contract violation on the relations between psychological contract breach and work- related attitudes and behaviours. Journal of Managerial Psychology, 24 (2), 136-160. doi: 10.1108/02683940910928856 
Swaen, V. \& Maignan, I.S.J. (2003). Organizational Citizenship and Corporate Citizenship: Two Constructs, One Research Theme? In True, S. \& Pelton, L. (Eds.), Business Rites, Writs and Relationships (pp. 105130). Kennesaw, Georgia, USA: Kennesaw State University.

Waltz, S.M. \& Niehoff, B.P. (2000). Organizational Citizenship Behaviours: Their Relationship to Organizational Effectiveness. Journal of Hospitality \& Tourism Research, 24 (3), 301-319. doi: 10.1177/109634800002400301

Wang, L. Prieto, L., Hinrichs, K.T. \& Howell, J.P. (2013). Five dimensions of organizational citizenship behaviour: Comparing antecedents and levels of engagement in China and the USA. Asia Pacific Journal of Management, 30 (1), 115-147. doi: 10.1007/s10490-010-9237-1

Zhao, H., Wayne J.S., Glibkowski, C.B. \& Bravo, J. (2007). The impact of psychological contract breach on work-related outcomes: A meta-analysis. Personnel Psychology, 60 (3), 647-680. doi: 10.1111/j.17446570.2007.00087.x

\section{ISTRAŽIVANJE UTICAJA VRSTA PSIHOLOŠKOG UGOVORA NA ORGANIZACIONO PONAS̆ANJE}

Organizaciono građansko ponašanje predstavlja ponašanje zaposlenih koji prevazilazi njihove dužnosti. Ovakvo ponašanje iz perspektive poslodavca je veoma poželjno, jer donosi mnoge pozitivne posledice u pogledu individualnih i ukupnih organizacionih performansi. Međutim, na spremnost zaposlenih da ispoljavaju ovakvu vrstu ponašanja utiču mnogi faktori. Jedan od najvažnijih je ispunjenje psihološkog ugovora zaposlenih. Pošto postoje dva osnovna oblika psihološkog ugovora, relacioni i transakcioni, cilj ovog rada je da istraži odnos između ovih vrsta ugovornog organizacionog građanskog ponašanja. U svrhu testiranja predloženih hipoteza, primenjeni su t-test, Pirsonova korelacija i višestruka linearna regresiona analiza. Rezultati su pokazali da postoji pozitivan odnos $i$ pozitivan uticaj relacionog psihološkog ugovora na organizaciono građansko ponašanje, što nije bio slučaj kada je reč o transakcionom ugovoru.

Ključne reči: relacioni psihološki ugovor, transakcioni psihološki ugovor, organizaciono građansko ponašanje, zaposleni. 